\title{
Evaluation of Stress Biomakers (Cytokines) in Presence of Unpredictable Chronic Stress (UCS) in Sprague Dawley Rats after Treatment with the Biofield Energy Treated Novel Proprietary Test Formulation
}

\author{
Trivedi $\mathrm{MK}^{1}$, Branton $\mathrm{A}^{1}$, Trivedi $\mathrm{D}^{1}$ and Jana $\mathrm{S}^{2 *}$ \\ ${ }^{1}$ Trivedi Global, Inc., Henderson, Nevada, USA \\ ${ }^{2}$ Trivedi Science Research Laboratory Pvt. Ltd., India
}

*Corresponding author: Snehasis Jana, Trivedi Science Research Laboratory Pvt. Ltd., Thane, Maharashtra, India, Email: publication@trivedisrl.com

\section{Research Article \\ Volume 4 Issue 2}

Received Date: June 25, 2021

Published Date: July 09, 2021

DOI: $10.23880 /$ aabsc-16000163

\section{Abstract}

Unpredictable chronic stress (UCS) model was used to evaluate the effect of Consciousness Energy Healing Treatment (the Trivedi Effect ${ }^{\circledR}$ ) on a novel test formulation in male Sprague Dawley (SD) rats for the estimation of serum cytokines such as TNF-Alpha, IFN-Gamma, IL-6, and IL-2, along with C-reactive protein (CRP) using ELISA assay. A test formulation was formulated including minerals (calcium, copper, iron, magnesium, selenium, and zinc), vitamins (ascorbic acid, alpha tocopherol, cholecalciferol, cyanocobalamin, and pyridoxine $\mathrm{HCl}$ ), cannabidiol isolate, Panax ginseng extract, and $\beta$-carotene. The constituents of the test formulation were divided into two parts; one part of each ingredient was defined as the untreated test formulation, while the other parts and three groups of animal received Biofield Energy Healing Treatment remotely by a renowned Biofield Energy Healer, Mr. Mahendra Kumar Trivedi. The cytokines estimation results showed that the level of IL-2 was reduced by $14.2 \%$ in Biofield Energy Treatment per se to the rats (G6) group as compared with the disease control group (G2). TNF- $\alpha$ level in serum was decreased by $11 \%$ in the G6 group as compared with the G2 group. IL-6 level in serum was decreased by $21.7 \%, 30.8 \%, 16.3 \%, 10.1 \%$, and $13.4 \%$ in the G5, G6, G7, G8, and G9 groups, respectively as compared with the G2. However, IFN- $\gamma$ level was decreased by $18.3 \%$ and $11 \%$ in the G6 and G9 groups, respectively as compared with the G4. Similarly, CRP level was significantly decreased by $25.8 \%, 15.2 \%$, and $14.6 \%$ in the G5, G6, and G7 groups respectively, as compared with the G4. All-inclusive, Mr. Trivedi's Biofield Energy Healing Treatment/Blessing per se along with other preventive treatment groups showed a significant impact on various inflammatory disorders (gout, inflammatory arthritis myositis, rheumatoid arthritis, scleroderma, etc.). Therefore, the outcomes could be slowdown the stress-related disease progression and its complications/symptoms in the preventive maintenance groups (viz. G6, G7, G8, and G9).

Keywords: Biofield Treatment; Stress Biomakers; Cytokines; The Trivedi Effect ${ }^{\circledR}$; Unpredictable Chronic Stress; ELISA

Abbreviations: UCS: Unpredictable Chronic Stress; SD: Sprague Dawley; IFN- $\alpha$ : Interferon-Alpha; TNF- $\alpha$ : Tumor Necrosis Factor; CBD: Cannabidiol; CAM: Complementary and Alternative Medicine; NCCIH: National Centre of Complementary and Integrative Health; NCCAM: National Center for Complementary/Alternative Medicine; CRP: 
C-Reactive Protein; CPCSEA: Committee for the Purpose of Control and Supervision of Experiments on Animals; SEM: Standard Error of Mean;

\section{Introduction}

Various neuropsychiatric disorders are considered to be triggered as a result of the stressful life events and such disorders are depression, anxiety, and dementia, etc. [1]. Moreover, such disorders may further accompanied by the immune dysfunction [2]. Several research studies reported that the chronic, unresolved stress could be considered as main risk factor behind the clinical depression. Also, the immune dysfunction induced due to prolonged stress is regarded to contribute and therefore increases the effects of stress on health [3]. Moreover, the exposure of body to chronic stress causes the neuropsychiatric alterations that include anxious-like behaviour [4,5], depressivelike behaviour [6], and cognitive deficits [7,8]. Although, the pathogenesis of psychiatric disorder remains largely unknown; however, various hypotheses were proposed regarding this that also include the cytokine hypothesis. This hypothesis was proposed in 1991 and it indicated that there is the role of pro-inflammatory cytokines in mediating the neuro-endocrine, behavioural, and neuro-chemical features of depressive disorders $[9,10]$. The cytokine hypothesis was proposed by scientists based on the idea that the activation of the inflammatory immune system, which specifically involved proinflammatory cytokines release, further stimulates various neurochemical and neuroendocrine changes, which are known as the contributing factor to depression [11]. There were several studies done using the stress protocols (physical, psychological or mixed) which shows that the pro-inflammatory response were mainly characterized by the release of various inflammatory mediators, such as, interleukin (IL)-1, IL-1 $\beta$, IL-6, interferonalpha (IFN- $\alpha$ ), tumor necrosis factor (TNF- $\alpha$ ), and cyclooxygenase-2 [12,13]. Another cytokine is interferongamma (IFN- $\gamma$ ) that is considered as another important mediator of both innate and adaptive immune responses. The research studies reported the major role of IFN- $\gamma$ in stressor-related psychological pathology [14]. Thus, the unpredictable chronic stress (UCS) could be considered as the main contributor for the development of depression, which basically acts by promoting the expression of proinflammatory cytokines [15].

Overall cytokines role has been reported in various types of infections and the growth of malignant tumors, as the immune-stimulants and mediating the inflammatory response in a variety of human diseases $[16,17]$. Thus, in order to study the change in serum cytokines in presence of unpredictable stress, a novel test formulation was designed with the combination of vital minerals (selenium, zinc, iron, calcium, copper, and magnesium), essential vitamins (cyanocobalamin, ascorbic acid, pyridoxine $\mathrm{HCl}$, alpha tocopherol, and cholecalciferol), and nutraceuticals ( $\beta$-carotene, Ginseng, cannabidiol isolate (CBD)). All the minerals and vitamins used in the test formulation have significant functional role to provide vital physiological role [18-20]. Besides, cannabidiol itself has wide range of pharmacological profile and was reported to role in different disorders [21,22], while ginseng extract is regarded as the one of the best immune booster for overall immunity [23]. The present study aimed to evaluate the effect of unpredictable chronic stress (UCS) on serum cytokines of male Sprague Dawley rats in presence of novel test formulation, which was treated with Biofield Energy Treatment (the Trivedi Effect ${ }^{\circledR}$ ).

Biofield Energy Healing Treatment has been reported with significant effects against many disorders, and defined as one of the best Complementary and Alternative Medicine (CAM) treatment approach [24-26]. National Center for Complementary/Alternative Medicine (NCCAM) recommended CAM with several clinical benefits as compared with the conventional treatment approach [27]. National Centre of Complementary and Integrative Health (NCCIH) accepted Biofield Energy Healing as a CAM health care approach in addition to other therapies such as deep breathing, natural products, Tai Chi, yoga, therapeutic touch, Johrei, Reiki, pranic healing, chiropractic/ osteopathic manipulation, guided imagery, meditation, massage, homeopathy, hypnotherapy, special diets, relaxation techniques, movement therapy, mindfulness, Ayurvedic medicine, traditional Chinese herbs and medicines in biological systems $[28,29]$. The Trivedi Effect ${ }^{\circledR}$ Consciousness Energy Healing Treatment was scientifically reported on various disciplines such as in the materials science [30,31], agriculture science [32], antiaging [33], gut health [34], nutraceuticals [35], pharmaceuticals [36], overall human health and wellness. In this study, the authors sought to study the impact of the Biofield Energy Treatment (the Trivedi Effect $^{\circledR}$ ) on the given novel test formulation and Biofield Energy Treatment per se to the animals serum cytokines in presence of UCS using standard ELISA assay.

\section{Materials and Methods}

\section{Chemicals and Reagents}

Pyridoxine hydrochloride (vitamin $\mathrm{B}_{6}$ ), calcitriol, zinc chloride, magnesium (II) gluconate, and $\beta$-carotene (retinol, provit A) were purchased from TCI, Japan. Copper chloride, cyanocobalamin (vitamin $\mathrm{B}_{12}$ ), calcium chloride, vitamin $\mathrm{E}$ (Alpha-Tocopherol), cholecalciferol (vitamin $\mathrm{D}_{3}$ ), iron (II) sulfate, and sodium carboxymethyl cellulose (Na-CMC) were procured from Sigma-Aldrich, USA. Ascorbic acid (vitamin C) and sodium selenate were obtained from Alfa Aesar, India. 
Cannabidiol isolate and Panax ginseng extract were obtained from Panacea Phytoextracts, India and Standard Hemp Company, USA, respectively. Imipramine hydrochloride was purchased from Sigma, USA. For the estimation of stress biomarker panel, and cytokines estimation, specific ELISA kits were used such as for detection of TNF-Alpha, C-reactive protein (CRP), IFN-Gamma, IL-6, and IL-2 were procured from CUSABIO, USA.

\section{Study Design}

The current experiment was designed to fulfil the study protocol, animals were assigned into nine (9) groups. G1: Normal control; G2: Disease control (UCS: Unpredictable chronic stress + 0.5\% CMC); G3: Reference item (UCS + Imipramine hydrochloride $30 \mathrm{mg} / \mathrm{kg}$ ); G4: (UCS + Untreated test formulation); G5: (UCS + Biofield Energy Treated test formulation); G6: (UCS + Biofield Energy Treatment per se to animals from day -15; G7: (UCS + Biofield Energy Treated test formulation from day -15); G8: (UCS + Biofield Energy Treatment per se plus Biofield Energy Treated test formulation from day -15), and G9: (UCS + Biofield Energy Treatment per se animals plus untreated test formulation).

\section{Maintenance of Animal}

Randomly breed male Sprague Dawley (SD) rats with body weight ranges from 200 to 300 gm were used in this study. The animals were purchased from M/s. Vivo Bio Tech, Hyderabad, India. Animals were randomly divided into nine groups based on their body weights consist of 6 animals of each group. They were kept individually in sterilized polypropylene cages with stainless steel top grill having provision for holding pellet feed and drinking water bottle fitted with stainless steel sipper tube. The animals were maintained as per standard protocol of the Committee for the Purpose of Control and Supervision of Experiments on Animals (CPCSEA), Ministry of Environment and Forest, Govt. of India. The test facility is registered (registration no. 64/PO/br/s/99/CPCSEA) for animal experiments with the CPCSEA. The animals were procured using protocol approved by the Animal Ethics Committee (IAEC/41/505) and the husbandry conditions were maintained as per the recommendations of the CPCSEA.

\section{Consciousness Energy Healing Strategies}

Each ingredient of the novel test formulation was divided into two parts. One part of the test compound was not received any sort of treatment and were defined as the untreated or control sample. The second part of the test formulation was treated with the Trivedi Effect ${ }^{\circledR}$ - Energy of Consciousness Healing Treatment (Biofield Energy Treatment) by a renowned Biofield Energy Healer, Mr.
Mahendra Kumar Trivedi under laboratory conditions for $\sim 3$ minutes. Besides, three group of animals also received Biofield Energy Treatment by Mr. Mahendra Kumar Trivedi under similar laboratory conditions for $\sim 3$ minutes. The Biofield Energy Healer was located in the USA, however the test formulation were located in the research laboratory of Dabur Research Foundation, New Delhi, India. The energy transmission was done remotely to the samples or animals. After that, the Biofield Energy Treated samples was kept in the similar sealed condition and used as per the study plan. In the same manner, the control test formulation group was subjected to "sham" healer for $\sim 3$ minutes, under the same laboratory conditions. The "sham" healer did not have any knowledge about the Biofield Energy Treatment/Blessing. The Biofield Energy Treated animals were also taken back to experimental room for further proceedings.

\section{Experimental Procedure}

Seven days after acclimatization, animals were randomized and grouped based on the body weight. Dosing for groups G7 and G8 were initiated on day -15 and continued till end of the experiment. However, G1 to G5 and G9 groups were dosed from day 1 till the end of experiment. G6 group was not to be dosed with the test formulation. Body weight and clinical signs were taken daily throughout the experimental period. Feed consumption was measured once in a week. All the animals except G1 group received stressinduced procedures such as sound stress, tilted cages and crowd stress, cold and warm water swim stress, food and water deprivation, stress due to change in the light and dark cycle were undergo seven different types of unpredictable stress procedures after scheduled dosing daily at specified interval to the end of the experiment for 8 weeks after the initiation of stress, which vary every week interval i.e. shuffling of stress type. During $8^{\text {th }}$ week of the experimental period, all the animals were individually subjected for blood collection for the experimental purpose.

\section{Sample Preparation for Cytokines}

After 8 weeks, animals were individually subjected for blood collection through retro-orbital route and the blood was collected in the plain vial, which was used for the separation of serum. The serum from all the groups was stored at $-20^{\circ} \mathrm{C}$ for further estimation.

\section{Estimation of Stress Biomarker Panel-Cytokine Levels and C-reactive protein (CRP)}

The serum from all the groups was subjected for the estimation of level of cytokines such as TNF-Alpha, IFNGamma, IL-6, and IL-2, along with C-reactive protein (CRP). All the stress biomarkers were estimated by ELISA as per 
manufacturer's information.

\section{Statistical Analysis}

The data were represented as mean \pm standard error of mean (SEM) and subjected to statistical analysis using Sigma-Plot statistical software (Version 11.0). For multiple comparison One-way analysis of variance (ANOVA) followed by post-hoc analysis by Dunnett's test and for between two groups comparison Student's t-test was performed. The $p \leq 0.05$ was considered as statistically significant.

\section{Results and Discussion}

\section{Estimation of Serum IL-2}

Stress has been reported to induce the level of cytokines (IL-2), which might be due to the major depression disorder. This type of continued stress may results in dysregulation of cytokines production and ultimately results in immunodepression that leads to various psychiatric disorders [37]. The level of serum IL-2 was detected in all the experimental groups and the data are presented in Figure 1.
The data suggested that unpredictable chronic stress group (G2) showed value of IL-2 as $78.83 \pm 4.0 \mathrm{pg} / \mathrm{mL}$, which was increased by $34.7 \%$ as compared with the normal control (G1, $58.51 \pm 3.1 \mathrm{pg} / \mathrm{mL}$ ). However, imipramine (positive control) treatment (G3) showed decreased serum IL-2 level by $6.7 \%$ i.e. $73.57 \pm 3.6 \mathrm{pg} / \mathrm{mL}$ was compared to the $\mathrm{G} 2$. On the other hand, untreated test formulation (G4) decreased the serum IL-2 level by $5.5 \%$ i.e. $74.46 \pm 4.0 \mathrm{pg} / \mathrm{mL}$ with reference to G2. Untreated test formulation group (G5) decreased serum IL-2 level, $77.17 \pm 7.1 \mathrm{pg} / \mathrm{mL}$ as compared to G2. Biofield Energy Healing/Blessing Treatment per se to the rats (G6) decreased serum IL-2 level, $67.60 \pm 4.2 \mathrm{pg} / \mathrm{mL}$ by $14.2 \%$ and $9.2 \%$ as compared to the G2 and G4 groups, respectively. G7 group (Biofield Energy Treated test formulation from day -15) increased serum IL-2 level, $86.94 \pm 7.5 \mathrm{pg} / \mathrm{mL}$ as compared to G2. G8 group (Biofield Energy Treatment per $s e+$ Biofield Energy Treated test formulation from day -15) increased serum IL-2 level, $92.22 \pm 9.2 \mathrm{pg} / \mathrm{mL}$ as compared to the G2. Similarly, G9 group (Biofield Energy Treatment per $s e+$ untreated test formulation from day -15) increased the serum IL-2 level, $91.64 \pm 6.7 \mathrm{pg} / \mathrm{mL}$ as compared to the G2.

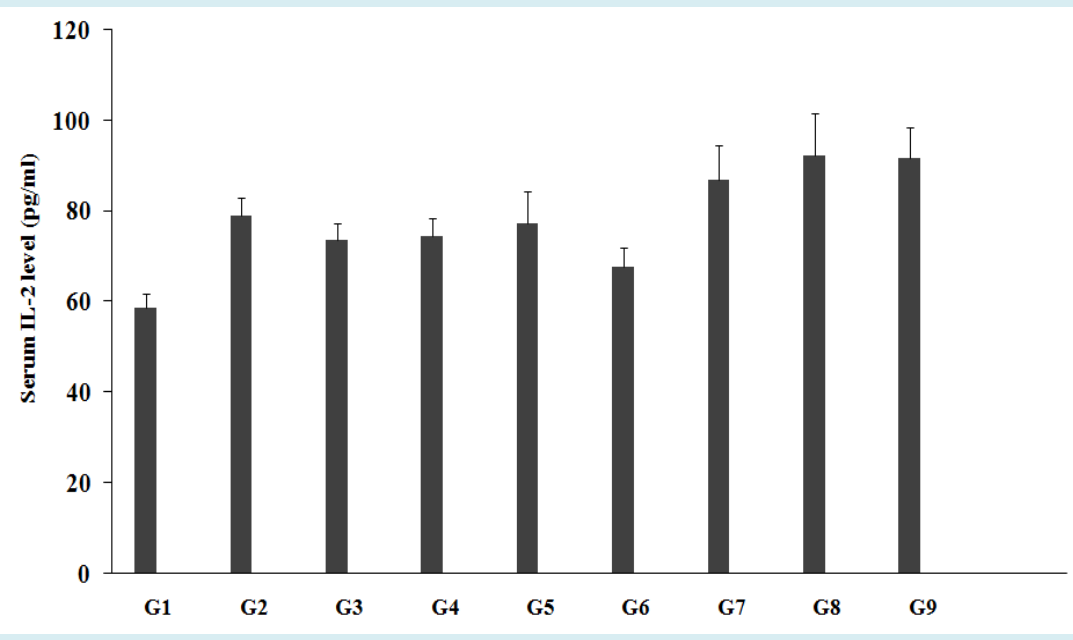

Figure 1: Expression the level of serum interleukin-2 (IL-2) after treatment with the Biofield Treated/Untreated proprietary test formulation and Biofield Energy Healing/Blessing per se to Sprague Dawley rats. G: Group; G1: Normal control; G2: Disease control (UCS: Unpredictable chronic stress + 0.5\% CMC); G3: Reference item (UCS + Imipramine hydrochloride $30 \mathrm{mg} / \mathrm{kg}$ ); G4: (UCS + Untreated test formulation); G5: (UCS + Biofield Energy Treated/Blessed test formulation); G6: (UCS + Biofield Energy Healing Treatment/Blessing per se to animals from day -15); G7: (UCS + Biofield Energy Treated test formulation from day -15); G8: (UCS + Biofield Energy Treatment per se + Biofield Energy Treated test formulation from day -15), and G9: (UCS + Biofield Energy Treatment per se to the animals + Untreated test formulation). All the data are shown as mean \pm SEM $(n=6)$.

\section{Estimation of Serum TNF- $\alpha$}

TNF- $\alpha$, a pro-inflammatory cytokines play a wide variety of role in body. These cell signaling protein (cytokine) significantly involved in systemic inflammation along with its important role in acute phase reaction. It mediates and regulates immune responses and inflammation, immune activation, that may involved in depressive symptoms in 
many cases. Thus, its alteration may results in depression and psychiatric disorders $[38,39]$. The effect of test formulation was compared with respect to the untreated test formulation and Biofield Energy Treatment per se. Serum cytokine, TNF- $\alpha$ was estimated in presence of the test formulation, and the data are graphically shown in Figure 2 . The data suggested that unpredictable chronic stress group (G2) showed value of TNF- $\alpha$ as $17.29 \pm 0.57 \mathrm{pg} / \mathrm{mL}$, which was increased by $11.4 \%$ as compared with the normal control (G1, $15.52 \pm 0.51 \mathrm{pg} /$ $\mathrm{mL}$ ). However, imipramine (positive control) treatment (G3) showed decreased serum TNF- $\alpha$ level by $9.2 \%$ i.e. 15.70 $\pm 0.22 \mathrm{pg} / \mathrm{mL}$ as compared to the G2. On the other hand, untreated test formulation (G4) decreased the serum TNF- $\alpha$ level by $11 \%$ i.e., $15.38 \pm 0.13 \mathrm{pg} / \mathrm{mL}$ with reference to $\mathrm{G} 2$ group. Biofield Energy Treated Test formulation animals (G5) decreased serum TNF- $\alpha$ level by $9.2 \%, 15.70 \pm 0.49 \mathrm{pg} / \mathrm{mL}$ as compared to G2 group. Biofield Energy Healing Treatment/ Blessing per se to the rats (G6) decreased serum TNF- $\alpha$ level, $15.38 \pm 0.32 \mathrm{pg} / \mathrm{mL}$ by $11 \%$ as compared to the G2. G7 group (Biofield Energy Treated test formulation from day -15) decreased serum TNF- $\alpha$ level by $8.4 \%, 15.84 \pm 0.37 \mathrm{pg} / \mathrm{mL}$ as compared to G2. G8 group (Biofield Energy Treatment per se + Biofield Energy Treated test formulation from day -15) decreased serum TNF- $\alpha$ level by $9 \%, 15.74 \pm 0.37 \mathrm{pg} / \mathrm{mL}$ as compared to the G2. Similarly, G9 group (Biofield Energy Treatment per se + untreated test formulation from day -15) decreased the serum TNF- $\alpha$ level by $5.7 \%, 16.30 \pm 0.24 \mathrm{pg} /$ $\mathrm{mL}$ as compared to the $\mathrm{G} 2$.

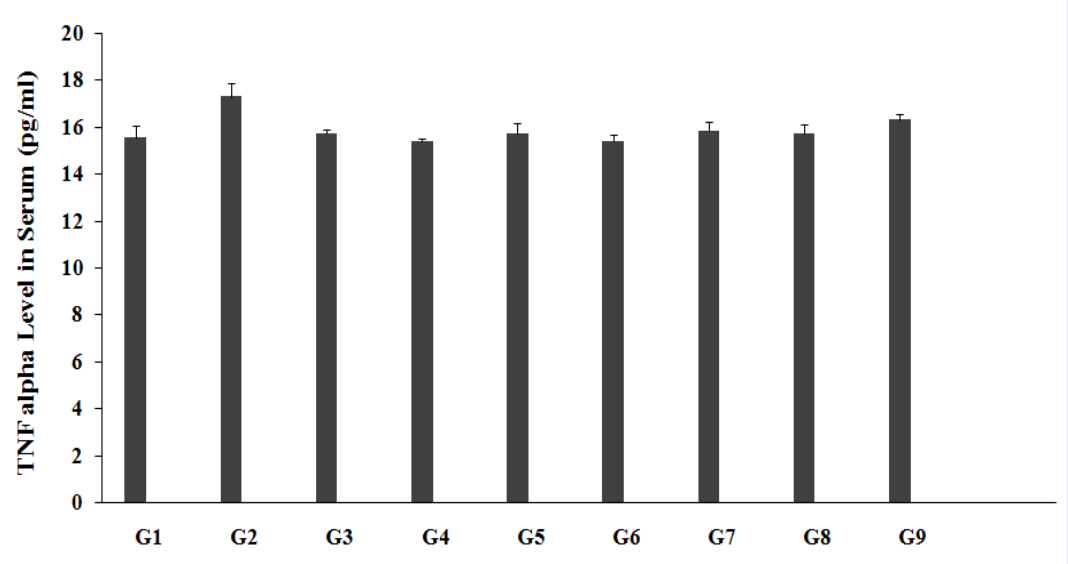

Figure 2: Expression the level of serum tumor necrosis factor-alpha (TNF- $\alpha$ ) after treatment with the Biofield Treated/ Untreated proprietary test formulation and Biofield Energy Healing/Blessing per se to Sprague Dawley rats.

\section{Estimation of Serum IL-6}

Stress induction was reported with high level of IL-6, thus, alteration and management in the level of cytokines has wide range of implicated in major depressive illness and its treatment. This is also regarded as the innate inflammatory response to many physical stressors (e.g., depression, traumatic stress, infection, inflammation) [40]. Expression the level of serum interleukin-6 (IL-6) after treatment with the Biofield Treated/Untreated proprietary test formulation and Biofield Energy Healing/Blessing per se to Sprague Dawley rats, and the results are shown in Figure 3. The data suggested that unpredictable chronic stress group (G2) showed value of IL-6 as $24.22 \pm 2.40 \mathrm{pg} / \mathrm{mL}$, which was significantly $(p \leq 0.001)$ increased by $121.1 \%$ as compared with the normal control (G1, $10.96 \pm 0.72 \mathrm{pg} / \mathrm{mL}$ ) group. However, imipramine (positive control) treatment (G3) showed decreased serum IL-6 level by $34.8 \%$ i.e. 15.80 $\pm 1.04 \mathrm{pg} / \mathrm{mL}$ as compared to the G2. On the other hand, untreated test formulation (G4) decreased the serum IL-6 level by $15.3 \%$ i.e., $20.52 \pm 0.78 \mathrm{pg} / \mathrm{mL}$ with reference to $\mathrm{G} 2$. Untreated test formulation group (G5) decreased serum IL-6 level by $21.7 \%, 18.96 \pm 1.05 \mathrm{pg} / \mathrm{mL}$ as compared to G2, while $7.6 \%$ decreased as compared with the G4 group. G6 group (Biofield Energy Treatment per se to animals from day -15) decreased serum IL-6 level, $16.77 \pm 1.26 \mathrm{pg} / \mathrm{mL}$ by $30.8 \%$ and $18.3 \%$ as compared to the G2 and G4 groups, respectively. G7 group (Biofield Energy Treated test formulation from day -15) decreased serum IL-6 level by $16.3 \%, 20.28 \pm 1.13 \mathrm{pg} /$ $\mathrm{mL}$ as compared to G2. G8 group (Biofield Energy Treatment per se + Biofield Energy Treated test formulation from day -15) decreased serum IL-6 level by $10.1 \%, 21.78 \pm 1.24 \mathrm{pg} /$ $\mathrm{mL}$ as compared to the G2. Moreover, G9 group (Biofield Energy Treatment per se + untreated test formulation from day -15 ) decreased the serum IL-6 level by $13.4 \%, 20.97 \pm$ $0.96 \mathrm{pg} / \mathrm{mL}$ as compared to the $\mathrm{G} 2$. 


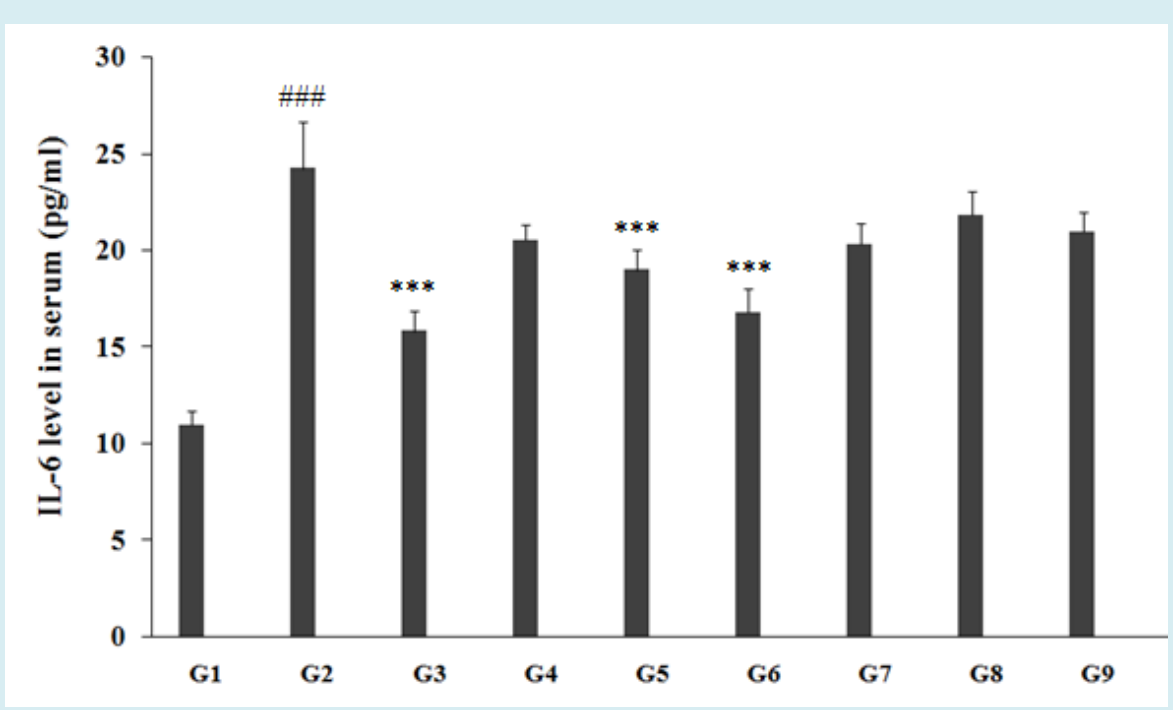

Figure 3: Expression the level of serum interleukin-6 (IL-6) after treatment with the Biofield Treated/Untreated proprietary test formulation and Biofield Energy Healing/Blessing per se to Sprague Dawley rats. \#\#\#p $\leq 0.001$ vs. G1 and ${ }^{* * *} p \leq 0.001$ vs. G2.

\section{Estimation of Serum IFN- $\gamma$}

Psychological stress has been reported to suppress the level of IFN- $\gamma[41,42]$. An alterations in the level of cytokine and immunomodulatory system have been reported in the development of stress-induced psychiatric disorders such as depression. Expression the level of serum IFN- $\gamma$ after treatment with the Biofield Treated/Untreated proprietary test formulation and Biofield Energy Healing/Blessing per se to Sprague Dawley rats, and the results are graphically shown in Figure 4.

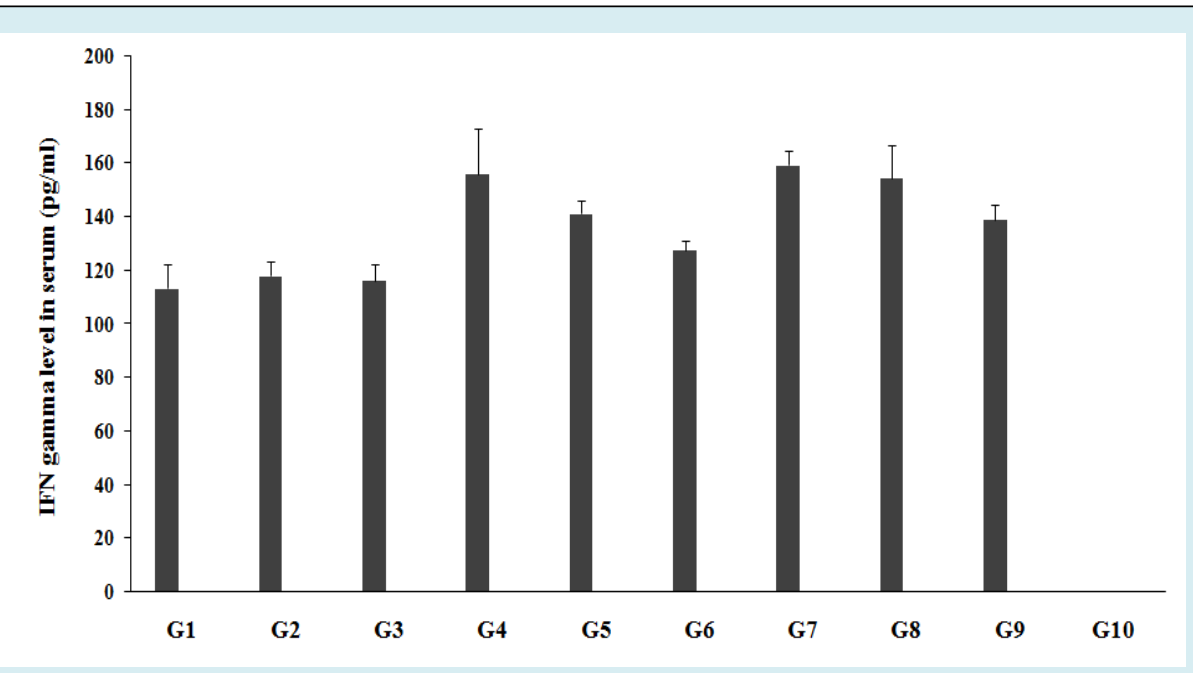

Figure 4: Expression the level of serum IFN- $\gamma$ after treatment with the Biofield Treated/Untreated proprietary test formulation and Biofield Energy Healing/Blessing per se to Sprague Dawley rats.

The data suggested that unpredictable chronic stress group (G2) showed value of IFN- $\gamma$ as $117.95 \pm 5.48 \mathrm{pg} / \mathrm{mL}$, which was increased by $4.1 \%$ as compared with the normal control $(\mathrm{G} 1,113.29 \pm 8.98 \mathrm{pg} / \mathrm{mL})$. However, imipramine (positive control) treatment (G3) showed a decreased serum IFN- $\gamma$ level $116.29 \pm 5.97 \mathrm{pg} / \mathrm{mL}$. On the other hand, untreated test formulation (G4) increased the serum IFN- $\gamma$ level by $32.3 \%$ i.e., $156.09 \pm 16.66 \mathrm{pg} / \mathrm{mL}$ with reference to G2 group. Biofield Energy Treated test formulation (G5) decreased serum IFN- $\gamma$ level by $9.5 \%, 141.23 \pm 5.02 \mathrm{pg} / \mathrm{mL}$ 
as compared to G4. G6 group (Biofield Energy Treatment per se to animals from day -15) decreased serum IFN- $\gamma$ level, $127.53 \pm 3.39 \mathrm{pg} / \mathrm{mL}$ by $18.3 \%$ as compared to the G4 group. G7 group (Biofield Energy Treated test formulation from day -15 ) increased serum IFN- $\gamma$ level by $35.1 \% ; 159.30 \pm 5.14 \mathrm{pg} /$ $\mathrm{mL}$, with respect to G2. G8 group (Biofield Energy Treatment per se + Biofield Energy Treated test formulation from day -15 ) increased serum IFN- $\gamma$ level by $30.9 \%$; $154.36 \pm 12.43$ $\mathrm{pg} / \mathrm{mL}$ as compared to the G4. Similarly, G9 group (Biofield Energy Treatment per se + untreated test formulation from day -15) decreased the serum IFN- $\gamma$ level by $11 \%, 138.87 \pm$ $5.74 \mathrm{pg} / \mathrm{mL}$ as compared to the G4.

\section{Estimation of Serum C - reactive protein (CRP)}

C-reactive protein (CRP) was reported is one of the best biomarker for detection ofimmune function alterations before initiation of any related psychiatric and medical disorders [43]. Atherosclerotic diseases along with many underlying inflammatory processes included the significance role of in the pathogenesis of disease trajectory. However, scientific data suggested that an increased level of CRP concentrations have been associated wide variety of pathological presence of mental disturbances such as depressive syndromes $[44,45]$, anxiety [46], and psychological distress [47,48]. Estimation the level of serum CRP after treatment with the Biofield Treated/Untreated proprietary test formulation and
Biofield Energy Healing/Blessing per se to Sprague Dawley rats, the results are plotted in Figure 5. The data suggested that unpredictable chronic stress group (G2) showed value of CRP as $148.40 \pm 32.45 \mathrm{ng} / \mathrm{mL}$, which was increased by $109.9 \%$ as compared with the normal control (G1, 70.69 $\pm 14.12 \mathrm{ng} / \mathrm{mL}$ ). However, imipramine (positive control) treatment (G3) showed decreased serum CRP level by $14.6 \%$, $126.69 \pm 20.93 \mathrm{ng} / \mathrm{mL}$ as compared with the G2. On the other hand, untreated test formulation (G4) increased the serum CRP level by $31.6 \%$ i.e., $195.26 \pm 45.25 \mathrm{ng} / \mathrm{mL}$ with reference to G2. Biofield Energy Treated test formulation (G5) decreased serum CRP level by $25.8 \%, 144.97 \pm 17.31$ $\mathrm{ng} / \mathrm{mL}$ as compared to the G4. G6 group (Biofield Energy Treatment per se to animals from day -15) decreased serum CRP level, $165.54 \pm 23.74 \mathrm{ng} / \mathrm{mL}$ by $15.2 \%$ as compared to the G4 group. G7 group (Biofield Energy Treated test formulation from day -15) decreased serum CRP level 166.69 $\pm 22.54 \mathrm{ng} / \mathrm{mL}$, by $14.6 \%$ with respect to the G4 group. G8 group (Biofield Energy Treatment per se + Biofield Energy Treated test formulation from day -15) altered serum CRP level $276.97 \pm 33.32 \mathrm{ng} / \mathrm{mL}$ as compared to the both G2 and G4 groups. Similarly, G9 group (Biofield Energy Treatment per se + untreated test formulation from day -15) altered the serum CRP level i.e., $218.69 \pm 31.64 \mathrm{ng} / \mathrm{mL}$ as compared to the both G2 and G4 groups.

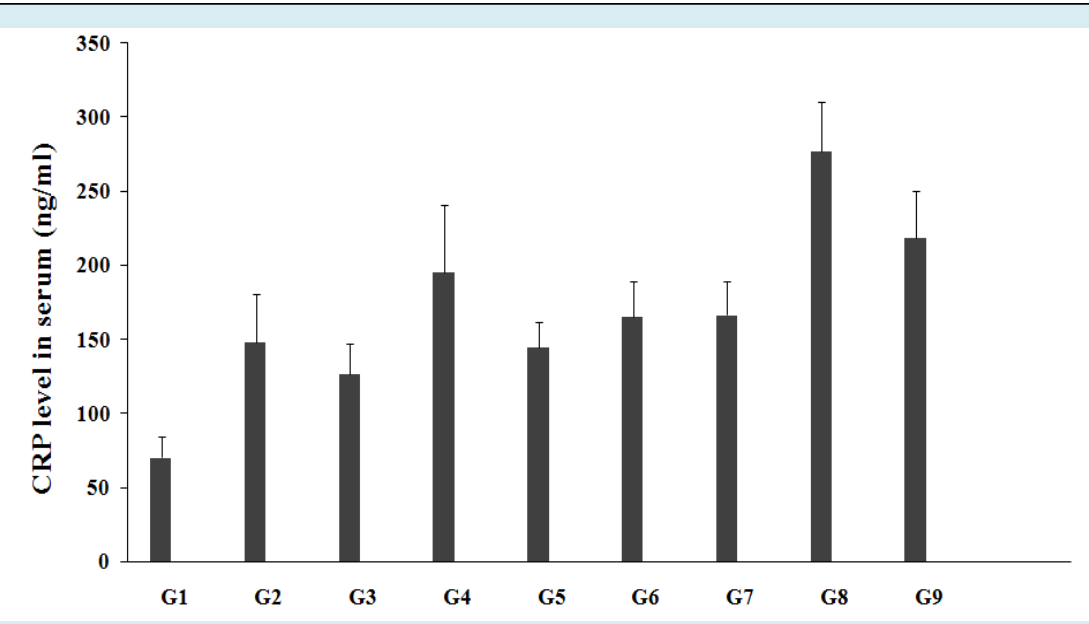

Figure 5: Estimation the level of serum CRP after treatment with the Biofield Treated/Untreated proprietary test formulation and Biofield Energy Healing/Blessing per se to Sprague Dawley rats.

Experiment includes four preventive maintenance groups (G6, G7, G8, and G9). The findings showed the significant slowdown of stress-related symptoms and also reduced the chances of disease susceptibility. Specifically, G6 group showed the best results as a prophylactic/preventive treatment compared to the other groups in rats. All-inclusive, it indicate that the Trivedi Effect ${ }^{\circledR}$ could be most effective and benefited to protect different kinds of diseases and also improve the overall health and quality of life. For better results it is necessary to extends further research in human populations, predominately. 


\section{Conclusion}

The present experimental data with special reference to serum cytokines revealed the significance role of Biofield Energy Treated/Blessed test formulation and Biofield Blessing per se on the animal stress level using various standard stresses induced models as compared with the other groups. Biofield Energy Healing/Blessing Treatment per se to the rats (G6) group showed decreased level of serum IL-2 level by $14.2 \%$ as compared with the disease control group (G2). Serum TNF- $\alpha$ in the G6 group was reported to be decreased by $11 \%$ as compared with the G2. However, the level of serum IL- 6 was significantly reduced by $21.7 \%$, $30.8 \%, 16.3 \%$, and $13.4 \%$ in the G5, G6, G7, and G9 groups, respectively, as compared with the G2. The level of IFN- $\gamma$ was found to decrease after treatment by $18.3 \%$ in the G6 group as compared with the G4. On the other hand, estimation of serum CRP data showed that the level was significantly decreased by $25.8 \%, 15.2 \%$, and $14.6 \%$ in the G5, G6, and G7 groups, respectively as compared with the G4, which showed improved pathogenesis of stress-related disorders. The Trivedi Effect ${ }^{\circledR}$ per se to the animals showed best results in the maintenance groups (G6, G7, G8, and G9) in rats. It can also aided to slowdown the disease progression rate and disease-related complications. The study data showed that Biofield Energy Treated Test formulation and Biofield Energy Treatment per se would be one of the best treatment strategies to prevent the manifestation of diseases. Thus, the Biofield Energy Treatment might act as a preventive maintenance therapy to maintain and improve the overall health and quality of life and simultaneously reduce the severity of acute/chronic diseases. The test formulation can also be used against rheumatoid arthritis (RA), fibromyalgia, aplastic anaemia, Addison disease (AD), multiple sclerosis, myasthenia gravis, psoriasis, Crohn's disease, ulcerative colitis, dermatitis, hepatitis, Parkinson's, stroke, etc.

\section{Acknowledgements}

The authors are grateful to Dabur Research Foundation, Trivedi Science, Trivedi Global, Inc., and Trivedi Master Wellness for the assistance and support during the work.

\section{References}

1. McEwen BS (2004) Protection and damage from acute and chronic stress: Allostasis and allostatic overload and relevance to the pathophysiology of psychiatric disorders. Ann N Y Acad Sci 1032: 1-7.

2. Glaser R, Kiecolt Glaser JK (2005) Stress-induced immune dysfunction: Implications for health. Nat Rev Immunol 5(3): 243-251.
3. Haroon E, Raison CL, Miller AH (2012) Psychoneuroimmunology meets neuropsychopharmacology: Translational implications of the impact of inflammation on behavior. Neuropsychopharmacology 37(1): 137-162.

4. Bondi CO, Rodriguez G, Gould GG, Frazer A, Morilak DA (2008) Chronic unpredictable stress induces a cognitive deficit and anxiety-like behavior in rats that is prevented by chronic antidepressant drug treatment. Neuropsychopharmacology 33(2): 320-331.

5. Pego JM, Morgado P, Pinto LG, Cerqueira JJ, Almeida OF, et al. (2008) Dissociation of the morphological correlates of stress-induced anxiety and fear. Eur J Neurosci 27(6): 1503-1516.

6. Strekalova T, Spanagel R, Bartsch D, Henn FA, Gass P (2004) Stress-induced anhedonia in mice is associated with deficits in forced swimming and exploration. Neuropsychopharmacology 29(11): 2007-2017.

7. Cerqueira JJ, Mailliet F, Almeida OF, Jay TM, Sousa N (2007) The prefrontal cortex as a key target of the maladaptive response to stress. J Neurosci 27(11): 27812787.

8. Conrad CD (2010) A critical review of chronic stress effects on spatial learning and memory. Prog Neuropsychopharmacol Biol Psychiatry 34(5): 742-755.

9. Serafini G, Pompili M, Elena Seretti M (2013) The role of inflammatory cytokines in suicidal behavior: A systematic review. Eur Neuropsychopharmacol 23(12): 1672-1686.

10. Takeshima M, Oka T (2015) DSM-5-defined 'mixed features' and Benazzi's mixed depression: Which is practically useful to discriminate bipolar disorder from unipolar depression in patients with depression? Psychiatry Clin Neurosci 69(2): 109-116.

11. Raison CL, Capuron L, Miller AH (2006) Cytokines sing the blues: Inflammation and the pathogenesis of depression. Trends Immunol 27(1): 24-31.

12. Steptoe A, Hamer M, Chida Y (2007) The effects of acute psychological stress on circulating inflammatory factors in humans: A review and meta-analysis. Brain Behav Immun 21(7): 901-912.

13. Assaf AM, Al Abbassi R, Al Binni M (2017) Academic stress-induced changes in Th1- and Th2-cytokine response. Saudi Pharm J 25(8): 1237-1247.

14. Litteljohn D, Nelson E, Hayley S (2014) IFN- $\gamma$ differentially modulates memory-related processes under basal and 
chronic stressor conditions. Front Cell Neurosci 8: 391.

15. Goshen I, Kreisel T, Zidon OBM (2008) Brain interleukin-1 mediates chronic stress-induced depression in mice via adrenocortical activation and hippocampal neurogenesis suppression. Mol Psychiatry 13(7): 717-728.

16. Zhao X, Fan W, Xu Z, Chen H, He Y, et al. (2016) Inhibiting tumor necrosis factor-alpha diminishes desmoplasia and inflammation to overcome chemoresistance in pancreatic ductal adenocarcinoma. Oncotarget 7(49): 81110-81122.

17. Li Q Zheng X (2017) Tumor necrosis factor alpha is a promising circulating biomarker for the development of obstructive sleep apnea syndrome: A meta-analysis. Oncotarget 8(16): 27616-27626.

18. Byrne JH, Voogt M, Turner KM, Eyles DW, McGrath JJ, et al. (2013) The impact of adult vitamin D deficiency on behaviour and brain function in male Sprague-Dawley rats. PLoS One 8(8): e71593.

19. Rayman MP (2000) The importance of selenium to human health. Lancet 356(9225): 233-241.

20. Beard JL, Connor JR (2003) Iron status and neural functioning. Ann Rev Nutr 23: 41-58.

21. Peres FF, Lima AC, Hallak JEC, Crippa JA, Silva RH, et al. (2018) Cannabidiol as a promising strategy to treat and prevent movement disorders? Front Pharmacol 9: 482.

22. Nagarkatti P, Pandey R, Rieder SA, Hegde VL, Nagarkatti $M$ (2009) Cannabinoids as novel anti-inflammatory drugs. Future Med Chem 1(7): 1333-1349.

23. Kang S, Min H (2012) Ginseng, the 'Immunity Boost': The effects of Panax ginseng on immune system. J Ginseng Res 36(4): 354-368.

24. Maizes V, Rakel D, Niemiec C (2009) Integrative medicine and patient-centered care. Explore (NY) 5(5): 277-289.

25. Bischof M, Del Giudice E (2013) Communication and the emergence of collective behavior in living organisms: A quantum approach. Mol Biol Int 2013: 987549.

26. Cassidy CM (2004) What does it mean to practice an energy medicine? J Altern Complement Med 10(1): 7981.

27. Barnes PM, Bloom B, Nahin RL (2008) Complementary and alternative medicine use among adults and children: United States, 2007. Natl Health Stat Report 12: 1-23.

28. Fan KW (2005) National center for complementary and alternative medicine website. J Med Libr Assoc 93(3): 410-412.

29. Wisneski L, Anderson L (2009) The Scientific Basis of Integrative Medicine. Evid Based Complement Alternat Med 2(2): 257-259.

30. Mahendra Kumar T, Alice B, Dahryn T, Snehasis J (2021) Effect of consciousness energy healing treatment on the metal profile and properties of tellurium. Eng Technol Open Acc 3(5): 555623.

31. Mahendra KT, Alice B, Dahryn T, Snehasis J (2021) Consciousness energy healing treatment impacted the isotopic abundance ratio of 6-Mercaptopurine (6-MP). Nov Appro Drug Des Dev 5(5): 555673.

32. Trivedi MK, Branton A, Trivedi D, Nayak G, Mondal SC, et al. (2015) Morphological characterization, quality, yield and DNA fingerprinting of biofield energy treated alphonso mango (Mangifera indica L.). Journal of Food and Nutrition Sciences 3: 245-250.

33. Trivedi MK, Jana S (2021) Anti-aging activity of biofield energy treated novel proprietary test formulation by assessment of vital biomarkers in cerebrospinal fluid (CSF) in Sprague Dawley rats. On J Neur Br Disord 5(2): 2021.

34. Mahendra Kumar T, Snehasis J (2021) Evaluation of biofield energy healing treatment based proprietary test formulation on gut health potential in colon cancer cell line (HT-29). J Pharmacol Clin Res 8(4): 555743.

35. Trivedi MK, Branton A, Trivedi D, Jana S (2021) Isotopic abundance ratio analysis of consciousness energy healing treated folic acid. Food Nutr Current Res 4(2): 290-295.

36. Trivedi MK, Branton A, Trivedi D, Jana S (2020) The consciousness energy healing treatment and its impact on the isotopic abundance ratio analysis of flutamide. Drug Des Int Prop Int J 3(5): 2020.

37. Himmerich H, Fischer J, Bauer K, Kirkby KC, Sack U, et al. (2013) Stress-induced cytokine changes in rats. Eur Cytokine Netw 24(2): 97-103.

38. Zou W, Feng R, Yang Y (2018) Changes in the serum levels of inflammatory cytokines in antidepressant drugnaïve patients with major depression. PLoS ONE 13(6): e0197267.

39. Dunn AJ, Swiergiel AH, De BR (2005) Cytokines as mediators of depression: What can we learn from animal studies? Neurosci Biobehav Rev 29(4-5): 891-909. 
40. Bob P, Raboch J, Maes M, Susta M, Pavlat J, et al. (2010) Depression, traumatic stress and interleukin-6. J Affect Disord 120(1-3): 231-234.

41. Wardhana M, Sudarmajaya S, Suryawati S, Rusyati LM (2018) Role of psychological stress on interferon-gamma (IFN- $\gamma$ ) in atopic dermatitis. Biomed Pharmacol J 11(2).

42. Curtin NM, Boyle NT, Mills KH, Connor TJ (2009) Psychological stress suppresses innate IFN-gamma production via glucocorticoid receptor activation: Reversal by the anxiolytic chlordiazepoxide. Brain Behav Immun 23(4): 535-547.

43. Carpenter LL, Gawuga CE, Tyrka AR, Price LH (2012) C-reactive protein, early life stress, and wellbeing in healthy adults. Acta Psychiatr Scand 126(6): 402-410.

44. Bankier B, Barajas J, Martinez Rumayor A, Januzzi JL (2009) Association between major depressive disorder and C-reactive protein levels in stable coronary heart disease patients. J Psychosom Res 66(3): 189-194.
45. Matthews KA, Schott LL, Bromberger JT, Cyranowski JM, Everson Rose SA, et al. (2010) Are there bi-directional associations between depressive symptoms and C-reactive protein in mid-life women? Brain Behav Immun 24(1): 96-101.

46. Pitsavos C, Panagiotakos DB, Papageorgiou C, Tsetsekou E, Soldatos C, et al. (2006) Anxiety in relation to inflammation and coagulation markers, among healthy adults: the ATTICA study. Atherosclerosis 185(2): 320326.

47. Goldman Mellor S, Brydon L, Steptoe A (2010) Psychological distress and circulating inflammatory markers in healthy young adults. Psychol Med 40(12): 2079-2087.

48. Fuligni AJ, Telzer EH, Bower J, Cole SW, Kiang L, et al. (2009) A preliminary study of daily interpersonal stress and C-reactive protein levels among adolescents from Latin American and European backgrounds. Psychosom Med 71(3): 329-333. 